\title{
Past Arctic aliens have passed away, current ones may stay
}

\author{
Inger Greve Alsos $\cdot$ Chris Ware $\cdot$ Reidar Elven
}

Received: 22 August 2014 / Accepted: 20 June 2015/Published online: 4 July 2015

(C) The Author(s) 2015. This article is published with open access at Springerlink.com

\begin{abstract}
Increased human activity and climate change are expected to increase the numbers and impact of alien species in the Arctic, but knowledge of alien species is poor in most Arctic regions. Through field investigations over the last 10 years, and review of alien vascular plant records for the high Arctic Archipelago Svalbard over the past 130 years, we explored long term trends in persistence and phenology. In total, 448 observations of 105 taxa have been recorded from 28 sites. Recent surveys at 18 of these sites revealed that alien species had disappeared at half
\end{abstract}

Electronic supplementary material The online version of this article (doi:10.1007/s10530-015-0937-9) contains supplementary material, which is available to authorized users.

\section{G. Alsos $(\bowtie) \cdot$ C. Ware}

Troms $\varnothing$ University Museum, University of Troms $\varnothing$,

Kvaløyvegen 30, Tromsö 9037, Norway

e-mail: inger.g.alsos@uit.no

C. Ware

School of Geography and Environmental Studies, University of Tasmania, Churchill Avenue, Sandy Bay, TAS 7005, Australia

C. Ware

Ecosystem Services, Commonwealth Scientific and Industrial Research Organisation (CSIRO), Clunies Ross

Street, Acton, ACT 2601, Australia

R. Elven

Natural History Museum, University of Oslo, Post Office Box 1172, Blindern, 0318 Oslo, Norway of them. Investigations at a further 49 sites characterised by former human activity and/or current tourist landing sites did not reveal any alien species. Patterns of alien species distribution suggest that greater alien species richness is more likely to be aligned with ongoing human inhabitation than sites of transient use. The probability of an alien species being in a more advanced phenological stage increased with higher mean July temperatures. As higher mean July temperatures are positively correlated with more recent year, the latter finding suggests a clear warming effect on the increased reproductive potential of alien plants, and thus an increased potential for spread in Svalbard. Given that both human activity and temperatures are expected to increase in the future, there is need to respond in policy and action to reduce the potential for further alien species introduction and spread in the Arctic.

Keywords Alien - Arctic - Climate change · Management · Non-native species · Phenology

\section{Introduction}

The proportion of alien species is lower in polar regions than elsewhere (Ellis et al. 2012; Elven et al. 2011; Frenot et al. 2005). Until recently, two processes have maintained the ecological integrity of these cold regions: low frequency of human-mediated dispersal, and the prevailing climate, both of which are rapidly 
changing (Thuiller et al. 2007; Walther et al. 2009). Propagule pressure, a primary determinant of alien species occurrence and spread (Carboni et al. 2011; Lockwood et al. 2005), is increasing in polar regions due to escalating human activity (Chown et al. 2012; Lassuy and Lewis 2013; Ware et al. 2012, 2013). Likewise, ongoing global warming has enabled alien species to expand into regions in which they previously could not survive and reproduce (Walther et al. 2009) and has increased invasion rates independent of propagule pressure in China, the United Kingdom, the Alps, and the United States (Huang et al. 2011; Marini et al. 2009). Ongoing climate change affects biodiversity most immediately through poleward and uphill range shifts (Kelly and Goulden 2008; Lenoir et al. 2008) and changes in phenology (Ovaskainen et al. 2013). The Arctic has so far experienced the highest rates of temperature increase globally, and is expected to continue to do so (Xu et al. 2013), with changes in phenology and range shifts observed already in Arctic species (Callaghan et al. 2011; Myers-Smith et al. 2011; Sturm et al. 2001). The establishment and spread of alien species in the Arctic has already increased and is expected to escalate dramatically in the near future (Wasowicz et al. 2013).

The Arctic represents a steep climatic gradient from the low Arctic with a mean July temperature of $10-12{ }^{\circ} \mathrm{C}$, to the polar desert zone with mean July temperatures of $1-3{ }^{\circ} \mathrm{C}$ (Walker et al. 2005). Whereas no alien vascular plant species have been recorded in the northernmost zones of the Arctic, the numbers of both casual and naturalized alien species increase towards its southern zones (Daniëls et al. 2013; Elven et al. 2011). The majority of Arctic aliens are confined to settlements and their close surroundings, trading posts, mining areas, airstrips, harbours, and the few roads and railways, and are not currently considered a threat to the native flora (Daniëls et al. 2013; Elven et al. 2011; Gederaas et al. 2012; Lassuy and Lewis 2013). However, in the low Arctic, plants introduced through agriculture in northern Fennoscandia, Iceland, and Greenland have been a significant part of local and regional floras for more than a millennium, and have caused substantial ecological impacts with establishment of hundreds of aliens and change of vegetation patterns (Elven et al. 2011). Furthermore, an increasing number of alien species -among them some ranked as highly invasive-have been recorded in the low Arctic and in all Arctic bordering zones: Alaska
(AKEPIC 2014; Carlson and Shepard 2007; Lassuy and Lewis 2013), Canada (http://www.wildspecies. ca), Greenland (http://nobanis.org/), Iceland (Wasowicz et al. 2013), Norway (Gederaas et al. 2012; Lembrechts et al. 2014), and Russia (Antipina 2003). These represent a large pool of alien species potentially able to invade the Arctic in the near future either by human-mediated or natural dispersal (Alsos et al. 2007; Ware et al. 2012).

While the awareness of risk of alien species transfer to the Antarctic has resulted in strict international biosecurity measurements (Hughes and Convey 2010; Huiskes et al. 2014), no equivalent measurements exist in the Arctic. The independent Arctic countries have each set aside variable areas of land as nature reserves in which the range of permitted activities are limited. Nevertheless, there is to our knowledge no compulsory biosecurity control measures in any Arctic region. While there is some indication that these are needed to minimize introduction and spread of aliens (Ware et al. 2012; Wasowicz et al. 2013), more knowledge is needed to design efficient measures (Hagen et al. 2012b).

Future change is best understood when measured against a credible baseline (Lassuy and Lewis 2013). However, with the exception of the small Arctic part of Iceland (Wasowicz et al. 2013), no comprehensive overview of alien species distribution or status exists for any Arctic region. The high Arctic archipelago Svalbard is among the best studied Arctic regions in terms of biodiversity (Elvebakk and Prestrud 1996; Prestrud et al. 2004). Accordingly, the higher number of casual alien species known from Svalbard compared to other Arctic regions (Elven et al. 2011) may be a result of survey bias. Svalbard was uninhabited until the first whaling stations were established in the early seventeenth century. The first records of vascular plants in Svalbard date back to 1675 (Malmgren 1862), whereas the first records of alien species were documented more than 200 years later, in 1883 (Gyllencreutz 1884), 1897 (Ekstam 1899), and 1898 (Andersson and Hesselman 1900). The flora of the archipelago was extensively investigated during the 20th century (e.g. Elvebakk 1989; Hadač 1944; Rønning 1972). However, with some exceptions (Hadač 1941; Høeg and Lid 1929; Sunding 1961), alien species were only sporadically recorded. In 1988, Liška and Soldán (2004) surveyed the surrounds of the two largest Russian mining settlements, 
Barentsburg and Pyramiden, and the latter was also surveyed in 2013 (Belkina et al. 2013). However, no attempts have been made to summarize all alien vascular plant species in Svalbard since 1941 (Hadač 1941). Here we: (1) present a complete record of all alien vascular plant species recorded in Svalbard based on field investigations and review of previous records; (2) evaluate whether phenological stage is related to temperature; and (3) based on the results of $1-2$, discuss implications for management.

\section{Materials and methods}

\section{Records of alien species}

Alien species were defined as species assumed to be of anthropogenic origin in Svalbard. The archipelago has a relatively short history of human population, and although there has been some discussion about the alien or native status of a few taxa (Engelskjøn and Schweitzer 1970; Alsos et al. 2015), aliens are generally recognised by being weedy species restricted to areas of human influence. Records of alien species were compiled from the literature, nobanis.org (no data prior to ours), and GBIF.org (last access date January 2015), and revision of all material in the Norwegian herbaria. Additional field investigations were undertaken in the current settlements of Barentsburg (in 2007, 2008, and 2011) and Longyearbyen (including Sverdrupbyen, Nybyen, and Hotellneset (2011), the recent settlement of Pyramiden (1998 and 2011) and settlements at Advent City and Hiorthhamn which were abandoned more than 50 years ago (2013). Further, brief visits were made to 17 stations in NW Svalbard in 2013. Surveys at all sites ranged between 2 and $6 \mathrm{~h}$. In addition, alien species have been recorded occasionally in Longyearbyen, and at trapper huts, research and weather stations, former whaling and mining sites, and research stations in 2006-2013 (Appendix S1). In addition, we included brief vegetation surveys made at tourist landing sites in 2008-2010 by Dagmar Hagen (AECO 2014; Hagen et al. 2012a). In total, results from 77 sites are reported here, including sub-sites within the largest settlements. The date of record and source of information is given for all sites (Appendix S1) and recorded species (Appendix S2). The records are conservative records of the true numbers of aliens, given that during the often brief visits taxa resembling native taxa (e.g. in Poa and Taraxacum), or plants were too young or too small to be detected, were overlooked. We follow the most recent taxonomy for the Arctic, the Panarctic Flora checklist (Elven et al. 2011). For species not mentioned there, we follow the United States Department of Agriculture/Natural Resources Conservation Service Plant Database (http://plants.usda.gov/java/).

As risk of alien species introduction may be related to the type and intensity of human activity, we collected related information including the type of activities undertaken at settlements, population sizes, any intentional species introduction, and animal husbandry (Appendix S1). In recent years, the largest settlement in Svalbard, the Norwegian mining, tourist, and science settlement of Longyearbyen, has had around 2000 inhabitants which is the highest ever recorded (Statistics Norway, http://ssb.no). At the time of the botanical investigations by Liška and Soldán in 1988, the Russian mining settlement of Pyramiden had about 1000 inhabitants (mining ceased in 1998 leaving only a few inhabitants connected with tourism and maintenance), whereas the Russian mining settlement of Barentsburg had 1200 inhabitants (there were about 400 inhabitants in 2014).

Phenology and climate

Phenological stages were classified where possible into 'vegetative', 'with flower bud', 'in flower (anthesis)', and 'with fruit', based on herbarium specimens or information given in the literature. Date of investigation or herbarium voucher collection was noted. For data by Ekstam (1899) and Liška and Soldán (2004), dates were given as "Autumn 1897 until 24th August" and 1st, 7th and 9th of August; the latest date of this period was used in the calculations. Dates were transformed to July date starting from July 1 st. Mean July temperature data were downloaded from eKlima for the period available (1915-2012 http://met.no).

\section{Statistics}

We modelled the effect of temperature and July date on the phenological stage of alien species as these variables are highly related to plant phenology (Lessard-Therrien et al. 2014). Also, as flower bud preformation in many cold adapted plants takes place in the prior season 
(Körner 2003), effect of temperature in the previous years was also fitted as a predictor variable. As the response variable of phenological stage was ordinal, we used cumulative link models due to their ability to incorporate the ordered nature of plants in various phenological stages. Models were fitted with three fixed effects: July date, the deviation of mean July temperature of the year of observation, and the deviation of mean July temperatures of year previous to the year of observation. As the data were hierarchically structured by the alien species identity (taxon), the site at which they were recorded, and also the year in which they were recorded, we additionally specified these three grouping structures as random terms. Specifying these terms allowed the thresholds between phenological stages to vary between different taxa, different years, and different survey sites (i.e. random thresholds). We considered that the latter might vary as a function of the more moderate microclimatic conditions characteristic of the larger settlements. As the year of observation was correlated with the deviation of mean July temperature $(r=0.7)$ we expected the influence of this term to be negligible in explaining variation in plant phenology; nevertheless, we retained it in the initial model. Model fit was assessed by simplifying models and removing interactions between fixed effects and assessing the impacts of simplification. The significance of model simplification was assessed by the magnitude of changes in Akaike's information criterion (AIC), and likelihood ratio tests. The latter was achieved by comparing models of different complexity using analysis of variance tests (ANOVA). Constant variance of the residuals, presence of outliers, and approximate normality of the random effects were checked graphically in final models. Parameter estimates were transformed from log-odds to odds, and we report the latter. All analyses were performed in R 3.1.3 (R Core Team 2013), and models were fitted using functions in the $\mathrm{R}$ package ordinal (Christensen 2015).

\section{Results}

Frequency and stability of introductions

A total of 373 records of alien species were found in the literature and herbarium records, and an additional 77 records were made during our field investigations (Appendix S1 and S2). In total, 450 observations of 105 taxa (including 7 taxa not determined to level of species or subspecies) had been reported from 28 sites (36 if sub-sites within settlements were counted). Taking into account the fact that multiple records of the same taxon within sites may represent re-sightings, this represents a minimum of 299 independent introductions of alien species. Among the 28 sites where alien taxa had been recorded during the last 130 years, they were still present at nine sites and absent from nine sites during our field investigations over the last 10 years. For the last ten sites, no recent observations were available. However, with the exception of for four sites on Bjørnøya where a total of 32 observations of eight species had been made, there had been a single observation of one species per site at the other six sites (Appendix 2). Highest numbers of records were found in the currently largest settlements Barentsburg (127), Longyearbyen (103) and the nearby Hotellneset (44), and Ny-Ålesund (56). Recent examination of 49 sites characterised by former human activity and/or current tourist landing site, but where no previous records were available, revealed no alien species (Fig. 1). Thus, all except one recent observation of alien species were recorded at current and abandoned settlements, whereas no introduced species were found at other sites with relatively high current visitation rates or sites undisturbed by humans (Appendix S1 and S2).

For the majority of taxa, fewer than ten records had been made: for eight taxa 10-20 records were made, and only Deschampsia cespitosa, Festuca rubra ssp. rubra, Poa pratensis ssp. pratensis and Stellaria media were recorded more than twenty times (Appendix S2). All except two species that had been observed ten times or more were observed in flower or fruit stages. In the two settlements Pyramiden and Barentsburg, where records are most comprehensive and where 40 alien species were observed in 1988, 28 taxa had disappeared, 12 had persisted, and 17 new species had been introduced (Appendix S2).

\section{Shift in phenology}

Data on phenology, mean July temperature, and July date were obtained collectively for 348 records. A model retaining the fixed effects of deviation from the mean July temperature and July date, and the random effect of taxonomic identity provided the best fit. For warmer relative to colder mean July temperature, the odds ratio of an average alien species being in a more 


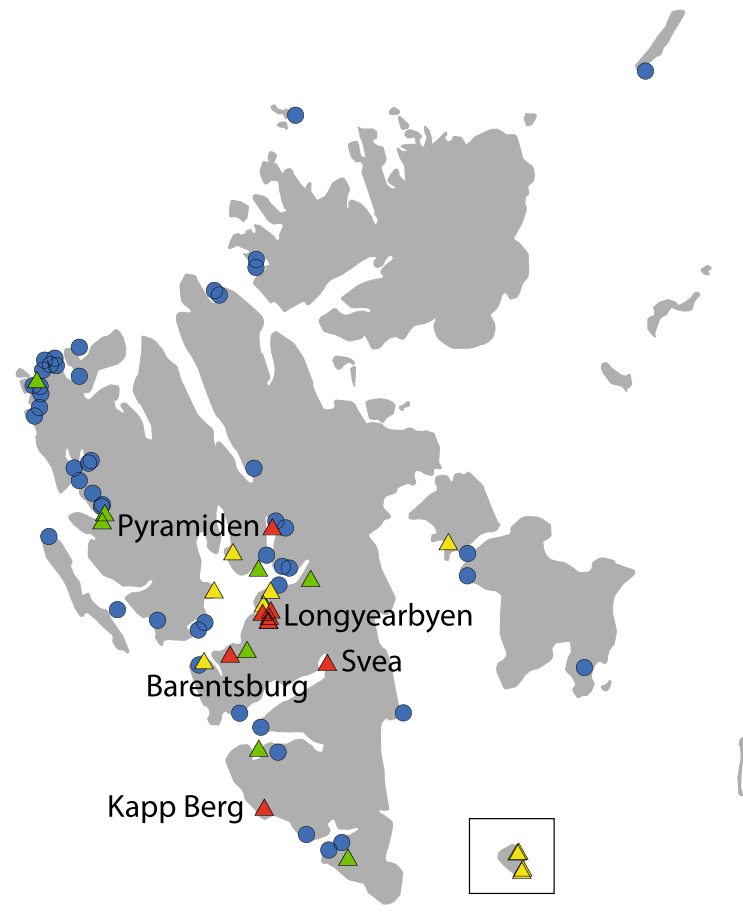

Fig. 1 Map of the high Arctic archipelago Svalbard. Triangles show sites where alien species have been recorded whereas circles show sites were no aliens have been recorded. Green triangles: earlier years but not recent years. Red triangles: both earlier and recent years (site names shown). Yellow triangles earlier years but no recent investigations performed. Blue circles: sites with former human activity and/or current tourist landing sites, where no older records of flora are available, and no alien species were found during recent investigations. The island of Bjørnøya is inset. See full list of sites in Appendix S1

advanced phenological stage was 1.469 , with the effect of July date being weaker but also positively associated with more advanced phenological stages (Table 1; Fig. 2). Neither the site at which alien species were recorded, nor the year of observation, explained a significant amount of variation in plant phenology. The estimated standard deviation (Table 1) of the random effect of taxonomic identity indicates, however, that phenological responses to warmer conditions differed among species (Table 2).

\section{Discussion}

Alien species in Svalbard

All the aliens recorded from Svalbard over the past 130 years (Appendix S2) are native to mainland
Europe (Tutin et al. 1964-2010), a finding that reflects the long history of European activity in Svalbard. The majority of records of aliens were from currently or formerly inhabited settlements suggesting their introduction was associated with higher levels of human traffic (Chown et al. 2012; Huiskes et al. 2014; Ware et al. 2012); animal husbandry and commerce practices in settlements (Coulson et al. 2013, 2015); and/or generally more favourable local climates. Data permitting the formal testing of the relative roles of these plausible introduction mechanisms are not available. Nevertheless, a widespread absence of recorded aliens at tourist landing sites outside settlements suggests that mechanisms other than sheer visitor numbers per $s e$ are the likely causes of most past introductions. Specific introduction routes may include the importation of animal fodder; attempts to produce lawns and green road verges in late twentieth century, and the transport of goods. From 1982, different seeding experiments were undertaken in Longyearbyen to make it appear more attractive, and larger scale seeding of the village centre was performed in the early 1990s (Hagen 2001). Of the planted species Festuca rubra ssp. rubra and Poa pratensis ssp. irrigata have persisted since then, both in high abundance. In Pyramiden, lawns were laid out c. 1983 using imported soils and regular fertilization by cattle dung (Coulson et al. 2015). These lawns are still present, with scattered occurrences of the alien species Achillea millefolium, Festuca rubra ssp. rubra and Deschampsia cespitosa. The dominant species, however,was identified as viviparous forms of the native species complex Poa arctica/pratensis (Elven and Alsos, pers. obs.), and is the result of seeding from local populations (Natalia Koroleva, pers. comm.). In Barentsburg, soil was imported for the greenhouse and later dumped below the cow shed, and continued dumping of dung may support alien persistence there.

Patterns of alien species persistence throughout Svalbard further support a conclusion that greening efforts and husbandry are the main sources of current aliens. Eight of the nine sites where aliens had previously been observed but not re-sighted in recent years (green triangles in Fig. 1) are abandoned now (Appendix 2). In the remaining inhabited settlement, Ny-Ålesund, records of aliens were made in the period 1920-1975. During this period the population reached up to 400 people and fodder was routinely imported for cows and horses. Following this period, Ny-Ålesund 
Table 1 Parameter estimates for the minimum adequate cumulative link mixed model

\begin{tabular}{lllcc}
\hline Model & Fixed effect & Estimate & SE & $z$ value \\
\hline Stage $\sim$ temp + date $+($ llspecies $)$ & Temp & 1.469 & 0.145 & 2.648 \\
& Date & 1.027 & 0.008 & 3.229 \\
\hline Model & Threshold coefficient & Estimate & SE & $z$ value \\
\hline Stage $\sim$ temp + date + (1lspecies) & Vegetativelbud & 1.479 & 0.5497 & 2.691 \\
& Budlflower & 2.459 & 0.568 & 4.329 \\
& Flowerlfruit & 6.046 & 0.681 & 8.873 \\
\hline Model & Random & Variation & SD & - \\
& effect & & & \\
\hline Stage $\sim$ temp + date $+(1$ lspecies $)$ & Species & 3.537 & \multirow{2}{*}{1.880} & - \\
\hline
\end{tabular}

The model fitted the cumulative probability of an observed alien species being in one of the four phenological stages or a less advanced stage based on two continuous climate-related fixed effects and the random effect of taxonomic identity. Parameter and threshold coefficient estimates are given as odds, and standard errors (SE) are presented for these whereas standard deviation (SD) is given for the random effect. The positive estimates for temp (deviation from the mean July temperature) and date (July date) indicate that higher values of these increase the probability of observing alien species in a more phenologically advanced stage

became a research station, and despite regular botanical records, no alien species have since been observed. There is also a possible role of more favourable climates in facilitating the establishment of aliens in settlements, relative to elsewhere around the archipelago, as most of the settlements are located in the climatically favourable parts of Svalbard, the bioclimatic subsone $\mathrm{C}$ (the midarctic tundra zone) (Elvebakk 2005). Only a few of the sites with records of aliens are within bioclimatic subzone B (the northern arctic tundra zone) (Ny-Ålesund, Kapp Berg, Calypsobyen, Hornsund, Virgohamna, Barentsøya). Thus, the widespread absence of alien records at tourist landing sites (typically being at the outer coasts in the north and south of Svalbard; bioclimatic subzone B), may be partly due to less favourable local climates at these sites. An additional factor limiting alien establishment at tourist landing sites may be soil erosion, as even relatively low levels of trampling by visitors may remove the soil cover (Hagen et al. 2012a).

The overall decrease in the range of aliens may reflect the decreasing number of inhabited settlements. Corroborating this, the decrease in the numbers of aliens at the settlements of Pyramiden and Barentsburg in later surveys, compared to the high numbers reported in extensive surveys in 1988 (Liška and Soldán 2004), points to greater levels of human activity as the cause of historically higher numbers of aliens. Animal husbandry, in particular, may mediate species introduction directly by introducing seeds with fodder, but also indirectly by increasing nutrient levels in soil, an especially limiting factor for plant growth in cold environments (Odasz 1994, Körner 2003).

\section{Comparison with other regions}

We record here about twice as many taxa (105) as previously recorded for Svalbard (36, Elven et al. 2011; 58, Gederaas et al. 2012), mainly due to more thorough revision of herbarium and literature records. The percentage of alien taxa recorded in Svalbard (57\%, 105 alien compared to 185 native, Alsos et al. 2015) was higher than recorded in any other Arctic region (Elven et al. 2011). This may reflect the overall higher degree of botanical observation and thorough revision of records on Svalbard, and we hypothesize that the proportion of aliens may be underestimated in other Arctic regions. Svalbard has considerably higher proportions of aliens than the mainly temperate-boreal Alaska $(13 \%, 283$ alien compared to 2100 native, Carlson and Shepard 2007) and Canada (24\%, 1252 alien compared to 5111 native, http://www. wildspecies.ca). It approaches the percentage found in temperate to boreal areas (e.g. Norway: $61 \%, 1719$ aliens, 2802 natives, Gederaas et al. 2012) and boreal to Arctic areas (e.g., Iceland $78 \%, 336$ aliens recorded 1840-2012, 429 natives, Wasowicz et al. 2013). While the exact numbers may depend on factors such as the 


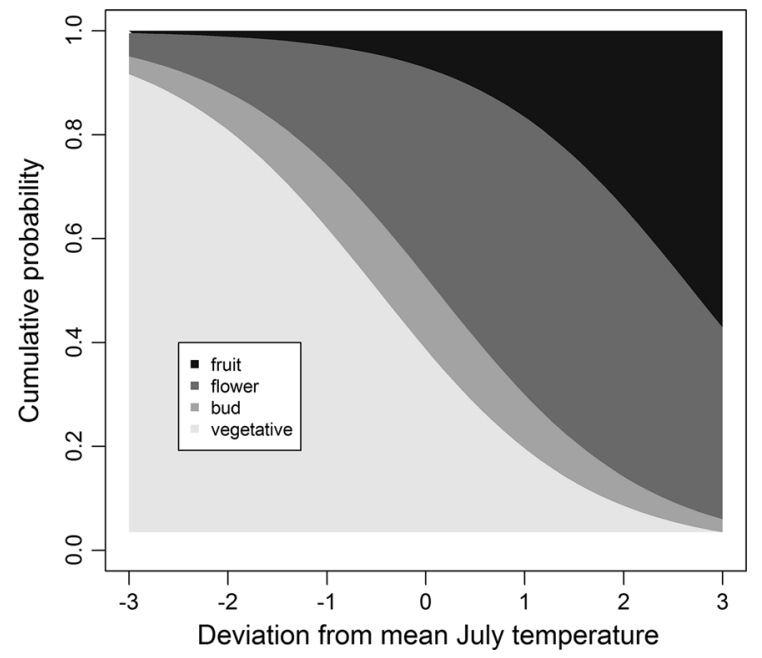

Fig. 2 Results from the cumulative link mixed model demonstrating the relationship between the phenological stages of observed alien species and deviation from mean July temperature. For an average alien species the probability of being in a fruiting stage was significantly higher at warmer relative to cooler temperatures as indicated by the vertical distance separating the cumulative probabilities for a given phenological transition with increasing temperatures

inclusion of casuals and survey effort, it is nevertheless clear that the proportion of recorded alien species in Svalbard is as high as in some non-Arctic regions. Furthermore, we assume that eleven species (10\%) are established based on their continued persistence over time as well as often being recorded in reproductive stages (i.e. flowers or fruits, Appendix S2). Of these, we consider one species (1\%, Anthriscus sylvestris) potentially invasive as it has produced mature fruits (Appendix 2), was not observed in 1988 (Liška and Soldán 2004) and therefore must have spread rapidly locally, is a known invasive (Iceland) or dominant ruderal (Norway) species elsewhere, and has the potential to transform the vegetation of bird cliffs in Svalbard (classified as "high impact", see Gederaas et al. 2012). These are broadly similar percentages of established and invasive aliens to those observed in other biomes (Vila et al. 2010), indicating that the risk of alien species becoming invasive in the Arctic is similar to that of other regions.

Effects of climate

A moderate climate warming signal (Førland et al. 2011) was detectable in our analyses of phenological change over time, with the probability of alien plants reaching a fertile stage increasing with warmer deviations from mean July temperatures and advancing July date. Given this, the likelihood of species spreading will increase with ongoing warming. Such a warming signal is apparent also in seed germination rates of native species, increases of which have been recorded over recent years (Alsos et al. 2013; Müller et al. 2011). Although climate change will likely have complex and multi-directional effects on alien species (Bellard et al. 2013), and will effect species differently (Tables 1,2), our data support the expectation that it will mainly favour the establishment and spread of alien species in the Arctic. A $3-4{ }^{\circ} \mathrm{C}$ increase in summer temperature is expected by 2100 (Førland et al. 2011), and this may affect alien species distributions on Svalbard in three ways. First, as the climate niche availability for casual aliens increasingly encompasses optimal performance thresholds (Petitpierre et al. 2012; Woodin et al. 2013), casual alien species will increasingly persist. Second, as the trend of increasing climatic suitability will likely also become apparent in the low Arctic and Arctic neighbouring territories, the potential donor pool of alien species will increase in diversity. Dispersal to Svalbard from this donor pool may be promoted by natural dispersal, for example due to extreme weather events (Coulson et al. 2002), but more pertinently due to increasing human traffic (Ware et al. 2012). Third, given the increasing probability of reproductive potential, it is possible that a greater number of alien species will become invasive, posing threats to native biota and ecosystem processes as already observed in Iceland (Anthriscus sylvestris; Wasowicz et al. 2013) and in the Antarctic (Taraxacum; Frenot et al. 2005).

\section{Implications for management}

The Svalbard Environmental Protection Act 2002 prohibits intentional introduction of alien species and thus effectively prevents future seeding and import of soil for greening purposes. However, fodder is still imported for horses in Longyearbyen and pigs in Barentsburg, and high concentration of aliens are found outside these farms today. Current aliens could be eradicated, and requiring the burning of animal manure is a simple measure that could be employed to limit potential future establishment. Other common sources of aliens, such as the ornamental plant trade and 
Table 2 Results of the model selection

\begin{tabular}{llllr}
\hline Dropped term & AIC & Log likelihood & $d f$ & $p$ \\
\hline Full model & 729.9423 & -354.9711 & & 1 \\
Year & 727.9423 & -354.9711 & 1 & 0.5807 \\
Site & 726.2474 & -355.1237 & 1 & 0.2645 \\
temp*temp_prev & 725.4926 & -355.7463 & 1 & 0.6206 \\
temp_prev & 723.7376 & -355.8688 & 1 & $<0.001$ \\
species & 836.6562 & -413.3281 & 1 & \\
\hline
\end{tabular}

Terms were dropped from the full cumulative link mixed model (phenological stage $\sim$ temp + temp_prev + date + temp* temp_prev + (1lspecies) + (1lyear) + (1lsite) sequentially to determine their significance in the model. Significance of the effects was determined by AIC and likelihood ratio tests. "Temp" deviation from the mean July temperature, "temp_prev" is deviation from the mean July temperature in the previous year

introduction through agriculture (Hendrichsen et al. 2015), are of limited relevance to the high Arctic (only one observation of potato cultivation and one of the ornamental plant Viola tricolor exist, both from Longyearbyen, Alsos pers. obs.), but adopting measures to ensure these activities do not present species invasion risks in the future seems prudent. Adopting a biosecurity framework modelled on existing Antarctic measures would provide more comprehensive protection (Hughes and Convey 2010; Huiskes et al. 2014). Such a framework may prove difficult to implement at the panArctic scale, but regional frameworks should be achievable in light of the success experienced in the Antarctic.

It is rather strikingly that no aliens were observed at tourist landing sites presently, as sites with rather low human activity in the Antarctic harbour aliens (Chown et al. 2012). The explanations may be that the numbers of visitors to most tourist landing sites have been low until recently (Hagen et al. 2012b) and that most visited sites are in climatically less favourable regions. It is likely, therefore, as tourism expands and climate warms, more aliens will establish in the future at landing sites around Svalbard. Surveillance should be focussed on areas with natural nutrient rich vegetation such as bird cliffs which may promote establishment and which are among the most species rich sites often harbouring redlisted species (Jonsdóttir 2005; Kålås et al. 2010). Also, less productive sites should be monitored if they harbour redlisted species (Westergaard et al. 2013; Evju et al. 2010). Whereas propagules introduced to settlements may be relatively easy to detect and eradicate, introductions from travellers at more pristine sites are likely to pose greater ecosystem risks as they may go undetected for long periods. The records of introduced species reported here, were, with few exceptions, made by professional botanists. The status of our knowledge of alien species could be greatly increased by engaging local residents as well as visitors to the Arctic in contributing to survey efforts. To facilitate identification, alien species should be included in regional flora guides across the Arctic as has been done for Svalbard (Alsos et al. 2015). This layer of additional survey effort could provide for cost-effective early detection monitoring. Also, the volunteer cleaning of shoes, currently adapted by the Association of Expedition Operators (AECO 2014), may be an efficient measure to minimize spread of aliens.

\section{Conclusions}

Our comprehensive evaluation of survey records demonstrating trends of alien species persistence, abundance, diversity, and phenology over time was made possible through a long history of botanical exploration in Svalbard. By collating and exploring these data, we have been able to demonstrate that alien species turnover has been substantial over the past century. More recent records are of more fertile plants compared to earlier records, constituting a phenological shift that we expect will promote the persistence and spread of current alien plants. The positive effect temperature has on alien plants also suggests an increasingly higher likelihood of any newly introduced species establishing. Simple management measures may greatly limit alien species introduction and spread, and should therefore be implemented. 
Acknowledgments We thank Geir Arnesen, Marie Kristine Føreid, Gunn Anne Sommersel, and Elin Lien for exploration of sites during the Governor of Svalbard's expedition in 2013, Dagmar Hagen, Pernille Bronken Eidesen, and Eike Müller for information on sites, Dorothee Ehrich for help with the statistics, the University Centre in Svalbard for help with logistics, and two anonymous reviewers for valuable contribution to improve the manuscript. We thank the Svalbard Environmental Protection fund for financial support (SMF 10-76 and 12-91 to I.G. Alsos).

\section{Compliance with Ethical Standards}

Conflict of interest We declare that we have no conflict of interest.

Open Access This article is distributed under the terms of the Creative Commons Attribution 4.0 International License (http:// creativecommons.org/licenses/by/4.0/), which permits unrestricted use, distribution, and reproduction in any medium, provided you give appropriate credit to the original author(s) and the source, provide a link to the Creative Commons license, and indicate if changes were made.

\section{References}

AECO (2014) Association of Arctic Expedition Cruise Operators. http://www.aeco.no/

AKEPIC (2014) Alaskan exotic plant information clearinghouse. http://aknhp.uaa.alaska.edu/

Alsos IG et al (2007) Frequent long-distance colonization in the changing Arctic. Science 316:1606-1609. doi:10.1126/ science. 1139178

Alsos IG, Müller E, Eidesen P (2013) Germinating seeds or bulbils in 87 of 113 tested Arctic species indicate potential for ex situ seed bank storage. Polar Biol 36:819-830. doi:10.1007/s00300-013-1307-7

Alsos IG, Arnesen G, Sandbakk BE, Elven R (2015) The flora of Svalbard. http://svalbardflora.net

Andersson G, Hesselman H (1900) Bidrag till kännedomen om Spetsbergens och Beeren Eilands kärlväxtflora grundade på iakttagelser under 1889 års svenska polarexpedition (Contribution to the knowledge of Spitsbergen and Beer Islands vascular flora based on observations under the 1889 Swedish polar expedition). Bih K Svenska Vet Akad Handl 26:1-88

Antipina GS (2003) Urban flora as a component of the urban ecosystems in the taiga zone: an example of karelian cities. Russ J Ecol 34:215-218. doi:10.1023/a:1024531712531

Belkina $\mathrm{O}$ et al. (2013) The study of flora and vegetation of Pyramiden settlement and its vicinity. Russian Academy of Sciences N.A. Avrorin Polar-Alpine Botanical Garden, Apatity

Bellard C, Thuiller W, Leroy B, Genovesi P, Bakkenes M, Courchamp F (2013) Will climate change promote future invasions? Global Change Biol 19:3740-3748

Callaghan TV, Christensen TR, Jantze EJ (2011) Plant and vegetation dynamics on Disko Island, West Greenland: snapshots separated by over 40 years. Ambio 40:624-637. doi:10.1007/s13280-011-0169-x
Carboni M, Santoro R, Acosta ATR (2011) Dealing with scarce data to understand how environmental gradients and propagule pressure shape fine-scale alien distribution patterns on coastal dunes. J Veg Sci 22:751-765. doi:10.1111/ j.1654-1103.2011.01303.x

Carlson ML, Shepard M (2007) Is the spread of non-native plants in Alaska accelerating?. US Department of Agriculture, Forest Service, Pacific Northwest Research Station, Portland

Chown SL et al (2012) Continent-wide risk assessment for the establishment of nonindigenous species in Antarctica. Proc Natl Acad Sci 109:4938-4943. doi:10.1073/pnas.111978 7109

Christensen RHB (2015) Ordinal-Regression Models for Ordinal Data. R package version 2015.1-21. http://www. cran.r-project.org/package=ordinal/

Coulson SJ, Hodkinson ID, Webb NR, Mikkola K, Harrison JA, Pedgley DE (2002) Aerial colonization of high Arctic islands by invertebrates: the diamondback moth Plutella xylostella (Lepidoptera: Yponomeutidae) as a potential indicator species. Divers Distrib 8:327-334

Coulson S et al (2013) Introduction of invertebrates into the High Arctic via imported soils: the case of Barentsburg in the Svalbard. Biol Invasions 15:1-5. doi:10.1007/s10530012-0277-y

Coulson S et al (2015) Microarthropod communities of industrially disturbed or imported soils in the High Arctic; the abandoned coal mining town of Pyramiden. Biodivers Conserv, Svalbard. doi:10.1007/s10531-015-0885-9

Daniëls FJA et al (2013) Plants. In: Meltofte H (ed) Arctic biodiversity assessment. Status and trends in Arctic biodiversity. Conservation of Arctic Flora and Fauna, Akureyri, pp 310-353

Ekstam O (1899) Beitrage zur Kenntnis der Gefässpflanzen Spitsbergens. (Contribution to the vascular flora of Spitsbergen). Troms $\emptyset$ Museums Aarshefter 20(1897):67-71

Ellis EC, Antill EC, Kreft H (2012) All is not loss: plant biodiversity in the Anthropocene. PLoS ONE 7:e30535. doi:10.1371/journal.pone.0030535

Elvebakk A (1989) Biogeographical zones of Svalbard and adjacent areas based on botanical criteria. PhD Thesis, University of Troms $\varnothing$

Elvebakk A (2005) A vegetation map of Svalbard on the scale 1:3.5 mill. Phytocoenologia 35:951-967

Elvebakk A, Prestrud P (1996) A catalog of Svalbard plants, fungi, algae and cyanobacteria. Norsk Polarinst Skr 198:9-55

Elven R, Murray DF, Razzhivin VY, Yurtsev BA (2011) Annotated checklist of the Panarctic Flora (PAF). Vascular plants. University of Oslo. http://nhm2.uio.no/paf/. 2013

Engelskjøn T, Schweitzer HJ (1970) Studies on the flora of Bear Island (Bjørnøya). I. Vascular plants. Astarte 3:1-36

Evju M, Blumentrath S, Hagen D (2010) Nordaust-Svalbard og Søraust-Svalbard naturreservater. Kunnskapsstatus for flora og vegetasjon (Northeast Svalbard and Southeast Svalbard nature reserves. Status of knowledge about flora and vegetation) vol 554. Norwegian Institute for Nature Research, Trondheim

Førland EJ, Benestad R, Hanssen-Bauer I, Haugen JE, Skaugen TE (2011) Temperature and precipitation development at Svalbard 1900-2100. Adv Meteorol. doi:10.1155/2011/ 893790 
Frenot Y, Chown SL, Whinam J, Selkirk PM, Convey P, Skotnicki M, Bergstrom DM (2005) Biological invasions in the Antarctic: extent, impacts and implications. Biol Rev 80:45-72. doi:10.1017/s1464793104006542

Gederaas L, Moen T, Skjelseth S, Larsen L-K (eds) (2012) Introduced species in Norway-with Norwegian black list. Artsdatabanken, Trondheim

Gyllencreutz R (1884) En trädgårdsanlägging på Spetsbergen. (Horticulture in Spitsvergen) Svenska trädgårdsföreningens tidskrift 6:8-11

Hadač E (1941) The introduced flora of Spitsbergen. Det Kongelige Departementet for Handel, Sjøfart, Industri, Håndverk og Fiskeri 49

Hadač E (1944) Die Gefässpflansen "Sassengebietes", Westspitsbergen. (Vascular flora of Sassen area, Westspitsbergen). Norges Svalbard og Ishavs-Unders $\varnothing$ kelser 87:72 pp. + XIV Tafel

Hagen D (2001) Botanikk og byfornyelse. A plukke blomster med bulldoser. (Botany and town renewal. To pick flowers with bulldozer). In: Arlov TB (ed) Fra company town til folkestyre: samfunnsbygging i Longyearbyen på $78^{\circ}$ nord (From company town to democracy: community building in Longyearbyen at $78^{\circ}$ north). Longyearbyen, Svalbard samfunnsdrift, pp 155-163

Hagen D, Eide NE, Fangel K, Flyen AC, Vistad OI (2012a) Sårbarhetsvurdering og bruk av lokaliteter på Svalbard. Sluttrapport fra forskningsprosjektet "Miljøeffekter av ferdsel". (Vulnerability assessment and use of locailties in Svalbard. Final report from the project "environmetal effects of traffic". Vol 785. NINA

Hagen D, Vistad OI, Eide NE, Flyen AC, Fangel K (2012b) Managing visitor sites in Svalbard: from a precautionary approach towards knowledge-based management. Polar Res. doi:10.3402/polar.v31i0.18432

Hendrichsen DK, Åström J, Forsgren E, Skarpaas O (2015) Spredningsveier for fremmede arter i Norge (Pathways of alien introductions to Norway), vol 1091. Norwegian Institute for Nature Research, Trondheim

Høeg OA, Lid J (1929) Adventive plants in Spitsbergen. K Norske Vid Selsk Forh I 59:176-178

Huang D, Haack RA, Zhang R (2011) Does global warming increase establishment rates of invasive alien species? A centurial time series analysis. PLoS ONE 6:e24733. doi:10. 1371/journal.pone.0024733

Hughes KA, Convey P (2010) The protection of Antarctic terrestrial ecosystems from inter- and intra-continental transfer of non-indigenous species by human activities: a review of current systems and practices. Global Environ Change 20:96-112. doi:10.1016/j.gloenvcha.2009.09.005

Huiskes AHL et al (2014) Aliens in Antarctica: assessing transfer of plant propagules by human visitors to reduce invasion risk. Biol Conserv 171:278-284. doi:10.1016/j. biocon.2014.01.038

Jónsdóttir IS (2005) Terrestrial ecosystems on Svalbard: heterogeneity, complexity and fragility from an arctic island perspective. Biol Environ Proc Roy Irish Acad 105B: $155-165$

Kålås JA, Viken Å, Henriksen S, Skjelseth S (eds) (2010) Norsk rødliste for arter 2010 (Norwegian redlist for species). Artsdatabanken, Norge
Kelly AE, Goulden ML (2008) Rapid shifts in plant distribution with recent climate change. Proc Natl Acad Sci 105:11823-11826. doi:10.1073/pnas.0802891105

Körner C (2003) Alpine plant life. Functional plant ecology of high mountain ecosystems. Springer, Berlin

Lassuy DR, Lewis PN (2013) Invasive species: human-induced. In: Meltofte $\mathrm{H}$ (ed) Arctic biodiversity assessment. Status and trends in Arctic biodiversity. Conservation of Arctic Flora and Fauna, Akureyri, pp 558-565

Lembrechts JJ, Milbau A, Nijs I (2014) Alien roadside species more easily invade alpine than lowland plant communities in a subarctic mountain ecosystem. PLoS ONE 9:e89664. doi:10.1371/journal.pone.0089664

Lenoir J, Gégout JC, Marquet PA, Ruffray Pd, Brisse H (2008) A significant upward shift in plant species optimum elevation during the 20th century. Science 320:1768-1771

Lessard-Therrien M, Bolmgren K, Davies TJ (2014) Predicting flowering phenology in a subarctic plant community. Botany 92:749-756. doi:10.1139/cjb-2014-0026

Liška J, Soldán Z (2004) Alien vascular plants recorded from the Barentsburg and Pyramiden settlements, Svalbard. Preslia 76:279-290

Lockwood JL, Cassey P, Blackburn T (2005) The role of propagule pressure in explaining species invasions. Trends Ecol Evol 20:223-228. doi:10.1016/j.tree.2005.02.004

Malmgren J (1862) Öfversigt af Spetsbergens fanerogram-flora. (Overview of Spitsbergens vascular flora). K Vet-Akad Förh 3:229-268

Marini L, Gaston KJ, Prosser F, Hulme PE (2009) Contrasting response of native and alien plant species richness to environmental energy and human impact along alpine elevation gradients. Global Ecol Biogeogr 18:652-661. doi:10.1111/j.1466-8238.2009.00484.x

Müller E, Cooper EJ, Alsos IG (2011) Germinability of arctic plants is high in perceived optimal conditions but low in the field. Botany 89:337-348. doi:10.1139/b11-022

Myers-Smith IH et al (2011) Shrub expansion in tundra ecosystems: dynamics, impacts and research priorities. Environ Res Lett. doi:10.1088/1748-9326/6/4/045509

Odasz AM (1994) Nitrate reductase activity in vegetation below an arctic bird cliff, Svalbard, Norway. J Veg Sci 5:913-920

Ovaskainen O et al (2013) Community-level phenological response to climate change. Proc Natl Acad Sci 110:13434-13439. doi:10.1073/pnas.1305533110

Petitpierre B, Kueffer C, Broennimann O, Randin C, Daehler C, Guisan A (2012) Climatic niche shifts are rare among terrestrial plant invaders. Science 335:1344-1348. doi:10. 1126/science. 1215933

Prestrud P, Strøm H, Goldman HV (2004) A cataloug of the terrestrial and marine animals of Svalbard. Norwegian Polar Instritute, Troms $\emptyset$

R Core Team (2013) R: A language and environment for statistical computing Foundation for Statistical Computing. Austria, Vienna

Rønning OI (1972) The distribution of the vascular cryptogams and monocotyledons in Svalbard. Skr Kongel Norske Vidensk Selsk 24:1-63

Sturm M, Racine C, Tape K (2001) Increasing shrub abundance in the Arctic. Nature 411:546-547 
Sunding P (1961) Noen plantefunn fra Svalbard sommeren 1960 (Some plant finds from Svalbard durig the summer 1960). Blyttia 19:125-129

Thuiller W, Richardson DM, Midgley GF (2007) Will climate change promote alien plant invasions? In: Nentwig W (ed) Biological invasions, vol 193. Ecological Studies. Springer, Berlin, pp 197-211. doi:10.1007/978-3-54036920-2_12

Tutin TG, Heywood VH, Burges NA, Valentine DH, Walters SM, Webb DA (1964-2010) Flora Europaea. vol 1-5. Cambridge University Press, Cambridge

Vila M et al (2010) How well do we understand the impacts of alien species on ecosystem services? A pan-European, cross-taxa assessment. Front Ecol Environ 8:135-144. doi: $10.1890 / 080083$

Walker DA et al (2005) The circumpolar arctic vegetation map. J Veg Sci 16:267-282

Walther G-R et al (2009) Alien species in a warmer world: risks and opportunities. Trends Ecol Evol 24:686-693

Ware C, Bergstrom D, Müller E, Alsos I (2012) Humans introduce viable seeds to the Arctic on footwear. Biol Invasions 14:567-577. doi:10.1007/s10530-011-0098-4

Ware C et al (2013) Climate change, non-indigenous species and shipping: assessing the risk of species introduction to a
high-Arctic archipelago. Divers Distrib. doi:10.1111/ddi. 12117

Wasowicz P, Przedpelska-Wasowicz EM, Kristinsson H (2013) Alien vascular plants in Iceland: diversity, spatial patterns, temporal trends, and the impact of climate change. Flora Morph, Distr, Funct Ecol of Plants 208:648-673. doi:10. 1016/j.flora.2013.09.009

Westergaard KB, Hagen D, Blumentrath S, Evju M (2013) Kunnskapssammenstilling for flora og vegetasjon i nasjonalparkene Nordvest-Spitsbergen, Forlandet og SørSpitsbergen på Svalbard. (Compilation of knowledge of flora and vegetation in the national parks Northwest Spitsbergen, Forlandet and South Spitsbergen on Svalbard). vol 986. Norwegian Institute for Nature Research, Trondheim

Woodin SA, Hilbish TJ, Helmuth B, Jones SJ, Wethey DS (2013) Climate change, species distribution models, and physiological performance metrics: predicting when biogeographic models are likely to fail. Ecol Evol 3:3334-3346

$\mathrm{Xu} \mathrm{L}$ et al (2013) Temperature and vegetation seasonality diminishment over northern lands. Nature Clim Change 3:581-586. doi:10.1038/nclimate 1836 